\title{
Sediment Radioactivity Levels of Deep-Water Fishery Grounds in Antalya Bay
}

\author{
Süleyman Fatih Özmen ${ }^{1}$ (D), Olgaç Güven²]
}

Cite this article as: Ozmen, S. F. \& Guven, O. (2021). Sediment radioactivity levels of deep-water fishery grounds in Antalya bay. Aquatic Sciences and Engineering, 36(1), 29-33.

ORCID IDs of the author: S.F.Ö. 0000-0003-2168-124X O.G. 0000-0002-0920-673X

${ }^{1}$ Akdeniz University, Vocational School of Technical Sciences, Antalya, Turkey

${ }^{2}$ Akdeniz University, Faculty of Fisheries, Antalya, Turkey

Submitted:

04.04.2020

Revision Requested:

14.04.2020

Last Revision Received: 08.05.2020

Accepted:

24.05.2020

Online published:

26.10.2020

Correspondence:

Süleyman Fatih Özmen

E-mail:

fatihozmen@akdeniz.edu.tr

(c) Copyright 2021 The Author(s) Available online at

https://dergipark.org.tr/ase

\begin{abstract}
To evaluate the radiological load of the fisheries ground sediments of deep-water areas in the Antalya Bay, ${ }^{226} \mathrm{Ra},{ }^{232} \mathrm{Th},{ }^{40} \mathrm{~K}$ and ${ }^{137} \mathrm{Cs}$ activity concentration levels were measured with the Gamma Spectroscopy technique using a HighResolution Germanium Detector (HPGe). Sediment samples were collected from the seabed surface of five different depth ranges (between $400-800 \mathrm{~m}$ ). Detected mean radionuclide activities of ${ }^{226} \mathrm{Ra},{ }^{232} \mathrm{Th},{ }^{40} \mathrm{~K}$ and ${ }^{137} \mathrm{Cs}$ were $16.53 \pm 2.41,17.9 \pm 2.54$, $371.44 \pm 18.44$ and $3.91 \pm 1.27 \mathrm{~Bq} \mathrm{~kg}^{-1}$, respectively. The effect of the Chernobyl Nuclear Power Plant disaster in deep water sediments of Antalya Bay was observed. However, the detected radionuclide concentrations are at acceptable levels according to the International Atomic Energy Agency (IAEA).
\end{abstract}

Keywords: Marine sediment, HPGe, Natural radioactivity, ${ }^{137} \mathrm{Cs}$

\section{INTRODUCTION}

Antalya, with a 2.4 million population, is the fifth most populated city in Turkey. Increasing population size also increases urbanization and industrialization pressures. Moreover, as a tourism hub, the area hosts an increased population density through the tourism season (KTB, 2019). In addition to regional pollutant factors, additional pressure arising from current systems and atmospheric flows were reported for the coastal areas of the region (Özhan et al., 2016). Domestic, industrial, and agricultural wastes and river discharges were known to be the main source (80-90\%) of the marine pollution in the Mediterranean Sea coastline of Turkey (Yemenicioğlu, 2016). Moreover, offshore activities were considered to be the secondary sources of pollution (Yemenicioğlu, 2016).

Following the Chernobyl Nuclear Power Plant (Chernobyl NPP) disaster on 25 April 1986, a major radioactive $\left({ }^{137} \mathrm{Cs}\right)$ fallout was released into the environment. ${ }^{137} \mathrm{Cs}$, as a common fission product, is one of the most problematic radioisotopes due to its high-water solubility, meaning it easily spreads in the environment. Radionuclides adversely affect biota in the impact area (Yilmaz and Özmen 2019; Özmen and Yilmaz 2020). As a response to the Chernobyl NPP disaster and increasing radioactivity levels in the Marmara region, a radiation monitoring program was launched by the Turkey Atomic Energy Agency (TAEK, 2004). Within the framework of this program, the detected ${ }^{137} \mathrm{Cs}$ activity was $15 \mathrm{~Bq} \mathrm{~kg}^{-1}$ from $0-5 \mathrm{~cm}$ layer of soil in the Antalya region in 1995.

Deep sea grounds of Antalya are important areas for commercial deep-water fishing activities. Several different fish (Deval et al., 2018) and invertebrate species (Deval and Kapiris, 2016; Deval et al., 2017) are caught from these fishing grounds and marketed in the local fisheries markets. Despite several studies having been carried out in the region to assess the state of the pollution in the marine environment (Türkmen et al., 2014; Özhan, 2015; Yilmaz, 2020), to the best of our knowledge, no literature information is available on the radionuclide activity levels of deep-sea sediments. The present study aims i) 
to evaluate the activity levels of natural $\left({ }^{226} \mathrm{Ra},{ }^{232} \mathrm{Th},{ }^{40} \mathrm{~K}\right)$ and anthropogenic $\left({ }^{137} \mathrm{Cs}\right)$ radionuclide activities in the deep sea fishing grounds of Antalya Bay and ii) to create a reference database of radionuclide background activity for the region.

\section{MATERIALS AND METHODS}

\section{Sampling and sample preparation for radionuclide activity detection}

Surface sediment samples were collected to investigate the availability of natural $\left({ }^{226} \mathrm{Ra},{ }^{232} \mathrm{Th},{ }^{40} \mathrm{~K}\right)$ and artificial $\left({ }^{137} \mathrm{Cs}\right)$ radionuclides at deep sea fishing areas (400 - 800 m) in Antalya. Sediments accumulated in the trawl net during the deep-sea trawl hauls were transferred to the laboratory for the subsequent radionuclide analysis.

Prior to spectrometric measurement, samples were dried (72 hours) at room temperature and homogenized by grinding. The samples were weighed and filled into cylindrical containers $(\mathrm{r}=3 \mathrm{~cm}, \mathrm{~h}=6 \mathrm{~cm})$ by passing through a $2 \mathrm{~mm}$ sieve. Samples were stored for 30 days in an airtight manner in order to stabilize the Compton region and establish a radioactive equilibrium between ${ }^{226} \mathrm{Ra}$ and ${ }^{222} \mathrm{Rn}$ (Yaprak and Aslani, 2010).

\section{Radionuclide analysis}

Following the formation of radioactive equilibrium, the gamma spectroscopic measurements of the samples were performed by using an electrically cooled high purity Germanium detector (HPGe) of p-type coaxial, with a relative efficiency of $40 \%$ and 768 eV Full Width Half Maximum (FWHM) values at $122 \mathrm{keV}$ for ${ }^{60} \mathrm{Co}$ and $1.85 \mathrm{keV} \mathrm{FWHM}$ at $1332 \mathrm{keV}$ for ${ }^{\circ} \mathrm{Co}$. The energy calibration of the gamma spectrometer system was carried out with point sources, and IAEA RGU-1, RGTh-1, and RGK-1 radioactive standards of the same geometry as the samples were used for activity measurement. A detailed description of the measurement system has been given by Özmen et al. $(2013,2014)$.

All samples were placed into the detector chamber and counted for 86400 s. The ${ }^{226} \mathrm{Ra}$ activity concentrations of the samples were calculated by the $352 \mathrm{keV}\left({ }^{214} \mathrm{~Pb}\right)$ and $609 \mathrm{keV}\left({ }^{214} \mathrm{Bi}\right)$ energy peaks released from the ${ }^{238} \mathrm{U}$ decay series. ${ }^{232} \mathrm{Th}$ activity concentrations were calculated by the $911 \mathrm{keV}\left({ }^{228} \mathrm{Ac}\right), 583$ and $2615 \mathrm{keV}\left({ }^{208} \mathrm{Tl}\right)$ energy peaks. Both ${ }^{40} \mathrm{~K}$ and ${ }^{137} \mathrm{Cs}$ activity concentrations were evaluated by the $1461 \mathrm{keV}$ and $662 \mathrm{keV}$ energy peaks, respectively. Background measurements were also performed with an empty sample container before and after measurements. To calculate the radionuclide activity concentrations, the following equation has been used;

$$
A=\frac{N / t}{\varepsilon \cdot I_{\gamma \cdot} m}
$$

A: activity of radionuclide $\left(\mathrm{Bq} \mathrm{kg}{ }^{-1}\right), \mathrm{N}$ : net count of energy in total (background removed), t: live time (second), $\varepsilon$ : efficiency of HPGe detector, $\gamma$ : abundance of gamma ray and $m$; mass of sample in $\mathrm{kg}$.

\section{RESULTS AND DISCUSSION}

The detected radioactivity levels of deep-sea sediment samples were ranged from 10.65 to $23.76 \mathrm{~Bq} \mathrm{~kg}^{-1}$ for ${ }^{226} \mathrm{Ra}$, 11.63 to 24.15
$\mathrm{Bq} \mathrm{kg}{ }^{-1}$ for ${ }^{232} \mathrm{Th}$, from 316.35 to $414.83 \mathrm{~Bq} \mathrm{~kg}^{-1}$ for ${ }^{40} \mathrm{~K}$, and from 1.48 to $8.58 \mathrm{~Bq} \mathrm{~kg}^{-1}$ for ${ }^{137} \mathrm{Cs}$. Activity concentrations of radioisotopes ( ${ }^{226} \mathrm{Ra},{ }^{232} \mathrm{Th},{ }^{40} \mathrm{~K}$, and ${ }^{137} \mathrm{Cs}$ ) in sediments samples from different depths were given in Table 1.

Table 1. Radioactivity levels of the deep-sea sediments (Bq kg-1 dry weight).

\begin{tabular}{llccc}
\hline Depth $(\mathrm{m})$ & ${ }^{226} \mathrm{Ra}$ & ${ }^{232} \mathrm{Th}$ & ${ }^{40} \mathrm{~K}$ & ${ }^{137} \mathrm{Cs}$ \\
\hline $\mathbf{4 0 0}$ & 10.65 & 11.63 & 414.83 & 8.58 \\
$\mathbf{5 0 0}$ & 13.88 & 12.43 & 372.51 & 1.48 \\
$\mathbf{6 0 0}$ & 13.95 & 18.92 & 346.54 & 4.56 \\
$\mathbf{7 0 0}$ & 20.43 & 24.15 & 406.99 & 2.32 \\
$\mathbf{8 0 0}$ & 23.76 & 22.35 & 316.35 & 2.59
\end{tabular}

The correlations matrix of radioisotopes and depth were given in Table 2. A significant positive correlation between depth and concentrations of ${ }^{226} \mathrm{Ra}$ and ${ }^{232} \mathrm{Th}$ radioisotopes was observed $(p<0.05)$. However, no clear correlation was observed for ${ }^{40} \mathrm{~K}$. For ${ }^{137} \mathrm{C}$, with the exception of $500 \mathrm{~m}$ samples, a negative decreasing trend was observed with increasing depth. The correlation analysis between radioisotopes also revealed a positive strong relationship between ${ }^{226} \mathrm{Ra}$ and ${ }^{232} \mathrm{Th}$ isotopes.

Table 2. Correlations matrix of radioisotopes $\left({ }^{226} \mathrm{Ra}\right.$, ${ }^{232} \mathrm{Th},{ }^{40} \mathrm{~K},{ }^{137} \mathrm{Cs}$ ) and depth.

\begin{tabular}{lccccc}
\hline & ${ }^{226} \mathrm{Ra}$ & ${ }^{232} \mathrm{Th}$ & ${ }^{40} \mathrm{~K}$ & ${ }^{137} \mathrm{Cs}$ & Depth \\
\hline${ }^{226} \mathrm{Ra}$ & 1 & & & & \\
${ }^{232} \mathrm{Th}$ & $0.900^{*}$ & 1 & & & \\
${ }^{40} \mathrm{~K}$ & -0.700 & -0.400 & 1 & & \\
${ }^{137} \mathrm{Cs}$ & -0.300 & -0.400 & 0.200 & 1 & \\
Depth & $1.000^{* *}$ & $0.900^{\star}$ & -0.700 & -0.300 & 1 \\
\hline$\left.{ }^{*}\right)$ significance level $0.05,{ }^{(* *}$ significance level 0.01 & &
\end{tabular}

The detected activity levels of the naturally occurring radionuclide $\left({ }^{226} \mathrm{Ra},{ }^{232} \mathrm{Th},{ }^{40} \mathrm{~K}\right)$ were consistent with the activity levels reported from different regions of Turkey's surrounding seas. Furthermore, the levels of these radionuclide were below the worldwide mean activity levels ( ${ }^{226} \mathrm{Ra}: 35 \mathrm{~Bq} \mathrm{~kg}{ }^{-1},{ }^{232} \mathrm{Th}: 30 \mathrm{~Bq} \mathrm{~kg}^{-1},{ }^{40} \mathrm{~K}$ : $400 \mathrm{~Bq} \mathrm{~kg}^{-1}$ ). The regional activity levels of naturally occurring radionuclide were directly linked with the geochemical structure of the region and anthropogenic activities such as mining, oil, and gas exploration. Our results indicated that (for naturally occurring radionuclides) the study area could be classified as a normal area in a radiological point of view.

The main pathways of the naturally occurring radionuclide entrance into the marine environment were river transport, rain water, fallout, etc. Moreover, the activity concentration of these radionuclides was reported to be dependent on physicochemical parameters such as organic matter content and $\mathrm{pH}$ levels of sediments (Tripathi et al., 2013; Özmen, 2020). A slight decreasing trend of ${ }^{226} \mathrm{Ra}$ and ${ }^{232} \mathrm{Th}$ activity levels was reported with the increasing distance from shoreline and depth (coastal zone, max. 
Table 3. Literature information on radioactivity of the deep-sea marine sediments (Bq kg ${ }^{-1}$ dry weight).

\begin{tabular}{|c|c|c|c|c|c|c|c|c|}
\hline Region & Study Are & & ${ }^{226} \mathrm{Ra}$ & $232 \mathrm{Th}$ & ${ }^{40} \mathrm{~K}$ & ${ }^{137} \mathrm{Cs}$ & $\begin{array}{l}\text { Sam- } \\
\text { pling } \\
\text { Year }\end{array}$ & Literature \\
\hline \multirow{9}{*}{ 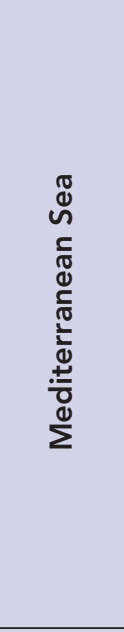 } & \multirow{2}{*}{$\begin{array}{l}\text { Antalya } \\
\text { Bay }\end{array}$} & Mean \pm SEM & $16.53 \pm 2.41$ & $17.90 \pm 2.54$ & $371.44 \pm 18.44$ & $3.91 \pm 1.27$ & \multirow{2}{*}{2019} & \multirow{2}{*}{ Present Study } \\
\hline & & Range & $10.65-23.76$ & $11.63-24.15$ & $316.35-414.83$ & $1.48-8.58$ & & \\
\hline & \multirow{2}{*}{$\begin{array}{l}\text { Marmara } \\
\text { Sea }\end{array}$} & $\mathrm{SPS}<63 \mu \mathrm{m}$ & $10.97-20.16$ & $13.97-27.25$ & $341.4-683.0$ & $8.58-67.92$ & \multirow{2}{*}{2008} & \multirow{2}{*}{$\begin{array}{c}\text { Kılıç \& } \\
\text { Cotuk, } 2011\end{array}$} \\
\hline & & SPS $>63 \mu \mathrm{m}$ & 7.18-19.18 & $6.41-18.30$ & 281.9-662.2 & $1.12-26.40$ & & \\
\hline & \multicolumn{2}{|c|}{ Izmit Bay } & $18 \pm 6$ & $24 \pm 8$ & $568 \pm 16$ & $21 \pm 2$ & $\begin{array}{l}2008- \\
2009\end{array}$ & Ergül et al., 2013 \\
\hline & \multirow{2}{*}{\multicolumn{2}{|c|}{ Greece }} & $9.7 \pm 5.4$ & $7.8 \pm 3.0$ & $132 \pm 54$ & $3.3 \pm 2.0$ & NA & $\begin{array}{c}\text { Papaefthymiou et } \\
\text { al., } 2017\end{array}$ \\
\hline & & & $18-86$ & $20-31$ & $368-610$ & $0.7-3.8$ & NA & Pappa et al., 2016 \\
\hline & \multicolumn{2}{|c|}{ Egypt } & $10.3-21.8$ & $11.9-34.4$ & $268-401$ & $2.7-15.9$ & 2002 & $\begin{array}{c}\text { El-Reefy et al., } \\
2010\end{array}$ \\
\hline & \multicolumn{2}{|c|}{ Spain } & 12.1 & 15.0 & 188 & NA & 2006 & $\begin{array}{c}\text { González- } \\
\text { Fernández et al., } \\
2012\end{array}$ \\
\hline \multirow{4}{*}{ 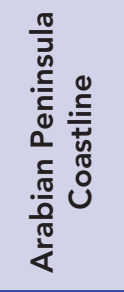 } & \multicolumn{2}{|c|}{ Oman Sea } & $11.83-22.68$ & $11.83-22.68$ & 222.89-535.07 & $0.14-2.8$ & 2011 & Zare et al., 2012 \\
\hline & \multicolumn{2}{|c|}{ Egypt (Red Sea) } & NA & $7.68-22.70$ & $160.0-356.8$ & $1.11-7.92$ & 2008 & $\begin{array}{c}\text { Dar \& El-Saharty, } \\
2012\end{array}$ \\
\hline & \multicolumn{2}{|c|}{ Kuwait } & 18.3-23.1 & $18.8-23.0$ & $386-489$ & $1.5-2.9$ & 2016 & $\begin{array}{c}\text { Uddin \& Behbe- } \\
\text { hani., } 2018\end{array}$ \\
\hline & \multicolumn{2}{|c|}{ Saudi Arabia } & $11.68 \pm 1.22$ & $6.21 \pm 0.58$ & $169.40 \pm 6.29$ & $0.76 \pm 0.120$ & $N A$ & $\begin{array}{c}\text { El-Taher et al., } \\
2018 \\
\end{array}$ \\
\hline \multirow{2}{*}{$\frac{\pi}{4}$} & \multicolumn{2}{|c|}{ Thailand } & $5-50$ & $4-108$ & $3-714$ & $B D L$ & NA & $\begin{array}{c}\text { Kritsananuwat et } \\
\text { al., } 2015\end{array}$ \\
\hline & \multicolumn{2}{|c|}{ India } & $34 \pm 15$ & $75 \pm 38$ & $782 \pm 233$ & NA & NA & $\begin{array}{c}\text { Tripathi et al., } \\
2013 \\
\end{array}$ \\
\hline 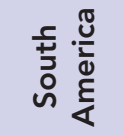 & \multicolumn{2}{|c|}{ Venezuela } & $2.6-28.9$ & $4.2-41.8$ & $15-421.2$ & $B D L$ & NA & $\begin{array}{l}\text { Alfonso et al., } \\
2014\end{array}$ \\
\hline
\end{tabular}

$15 \mathrm{~km}$ from shore line) from South East India due to the weathering and denudation activity of land (Tripathi et al., 2013). However, in our case, a distinct positive correlation between these radionuclides and depth was observed. Both elements resistance to weathering effects and/or the elements contents of the crustal rock as the source of release could be the main drivers of the ${ }^{226} \mathrm{Ra}$ and ${ }^{232} \mathrm{Th}$ distribution pattern in the study area.

It is known that Uranium (U) (mother of Radium) and Th deposition on the seabed mainly originated from land sources. The amount adsorbed on particulates that transferred through river runoff to marine environment desorbs in the high salinity medium of the sea. Uranium (U) solubility was reported to be one of the Th sources in the marine environment (Valkovic, 2000). Mean $U$ concentration in ocean water was given as $2.4 \mathrm{dpm} \mathrm{L} \mathrm{L}^{-1}(1.08 \mathrm{pCi}$ $\mathrm{L}^{-1}$ or $\left.3.25 \mu \mathrm{g} \mathrm{L}^{-1}\right)$. The produced Th by hydrolysis and adsorption processes is bound to the sinking particulate matter and ends up at the seabed. Our results revealed a significant correlation be- tween depth and ${ }^{232} \mathrm{Th}-{ }^{226} \mathrm{Ra}$ deposition. To understand the deposition dynamics of these radionuclides in the deep-water sediments, further investigation is needed.

The detected ${ }^{137} \mathrm{Cs}$ activity (mean: $3.91 \pm 1.27 \mathrm{~Bq} \mathrm{~kg}^{-1}$ ) in the sediments of the study area indicate the effect of the Chernobyl NPP disaster in deep water sediments of Antalya Bay. Our results were relatively lower than reported activity levels from northern parts of Turkey. Both the distance of the study area from ground zero and the sampling time were possible factors that lead to the low activity levels in the sediment. Another aspect that needs to be emphasized is the annual sinking rate of ${ }^{137} \mathrm{Cs}$ in marine sediments. Results of radionuclide monitoring activities between 1986-2002 from the Finnish coastline indicated an annual $1 \mathrm{~cm}$ sink of ${ }^{137} \mathrm{Cs}$ (Ilus et al., 2008). Moreover, several other studies also reported up to $1 \mathrm{~cm}$ sedimentation rates in the Mediterranean Sea (Othman et al., 2000; Zuo et al., 1997; Petrinec et al., 2012; Evangeliou et al., 2013). Due to this phenomenon a relative de- 
crease of ${ }^{137} \mathrm{Cs}$ activity in the marine surface sediment is expected through time.

While the main route of atmospheric radioactivity transfer to the sea is fall out, groundwater and rivers are the secondary contributor factor of the deposition to the sea (Zielinski, 2018). The main load of global ${ }^{137} \mathrm{Cs}$ fall out reported to be deposited in the sea was approximately 603 PBq (63.6\%). On the contrary, the total fall (85 PBq ${ }^{137} \mathrm{Cs}$ ) out from the Chernobyl NPP disaster was reported to be mainly deposited over land (69 PBq) (UNSCEAR, 2000). About $2 \%$ of ${ }^{137} \mathrm{Cs}$ is known to be removed by runoff from land deposition to the sea (Yamagata et al. 1963). Due to this phenomenon it is expected to detect higher ${ }^{137} \mathrm{Cs}$ activity levels in the coastal areas. Consistent with this, our results indicated that ${ }^{137} \mathrm{Cs}$ activity in marine sediments decreased with the depth. This outcome could be the result of deposition to the relatively shallow areas due to the impact of runoff in the study area. Moreover, evaluation of water column ${ }^{137} \mathrm{Cs}$ profiles, even with the impact of the Chernobyl NPP disaster, exhibits a steady decrease of activity up to $1000 \mathrm{~m}$ (Aarkrog, 2005).

\section{CONCLUSION}

Available literature on radionuclide activities in marine sediments mostly covers coastal area sediments from relatively shallow zones. The main focus of previous works was to understand the vertical distribution of the anthropogenic radionuclides $\left({ }^{137} \mathrm{Cs}\right.$ and $239,240 \mathrm{Pu}$ ) in the sediments to detect the state of pollution in the environment. The present study represents natural and artificial radionuclide activities of deep-sea surface sediments (400 $800 \mathrm{~m}$ ). Our results provide the background activity level of deep-sea sediments for the selected radionuclides. The detected activity levels for both naturally occurring and anthropogenic radionuclides in the deep-sea fishery areas of Antalya Bay were below the world average activity levels. It could be concluded that the consumption of seafood caught from these areas will not pose any radiological health risks. Further studies are needed to understand the active factors on the distribution dynamics of the radionuclides in deep sea areas.

Conflict of interests: There are no conflicts of interest to declare.

Ethics committee approval: Ethics committee approval is not required.

Funding: Sediment samples were collected during the field studies of research project "FBA-2019-4335" supported by Akdeniz University, Scientific Research Projects Coordination Unit.

Acknowledgments: We thank Prof. Dr. İsmail BOZTOSUN for providing gamma spectrometric measurements and his valuable support. Sediment samples were collected during the field studies of research project "FBA-2019-4335" supported by Akdeniz University, Scientific Research Projects Coordination Unit.

Disclosure: This study was presented at the "3rd International Water and Health Congress will be held $12^{\text {th }}-15^{\text {th }}$ November 2019 in Antalya".

\section{REFERENCES}

Aarkrog, A. (2005). Worldwide marine radioactivity studies (WOMARS). Radionuclide levels in oceans and seas. In Worldwide marine radioactivity studies (WOMARS). Radionuclide levels in oceans and seas (Vol. IAEA-TECDOC-1429)

Alfonso, J. A., Pe'rez, K., Palacios, D., Handt, H., LaBrecque, J.J., Mora A. \& Va'squez, Y. (2014). Distribution and environmental impact of radionuclides in marine sediments along the Venezuelan coast. $J$ Radioanal Nucl Chem, 300, 219-224. [CrossRef]

Dar, M. A. D. \& El-Saharty, A. A. (2012). Some Radioactive-Elements in the Coastal Sediments of the Mediterranean Sea. Radiation Protection Dosimetry, 1-8.

Deval, M. C., Kebapçioğlu, T., Güven, O. \& Olguner, M. T. (2018). Population pattern and dynamics of the Bluemouth Helicolenus dactylopterus (Delaroche, 1809) in the eastern Mediterranean Sea, Journal of Applied Ichthyology, 34, 568-580. [CrossRef]

Deval, M. C., Yilmaz, S. \& Kapiris, K. (2017). Spatio Temporal Variations in Decapod Crustacean Assemblages of Bathyal Ground in the Antalya Bay (Eastern Mediterranean). Turkish Journal of Fisheries and Aquatic Sciences, 17, 967-979.

Deval, M. C. \& Kapiris, K. (2016). A review of biological patterns of the blue-red shrimp Aristeus antennatus in the Mediterranean Sea: a case study of the population of Antalya Bay, eastern Mediterranean Sea, Scientia Marina, 80, 339-348. [CrossRef]

El-Reefy, H. I., Sharshar, T., Elnimr, T. \& Badran, H. M. (2010). Distribution of gamma-ray emitting radionuclides in the marine environment of the Burullus Lake: II. Bottom sediments. Environ Monit Assess, 169, 273-284. [CrossRef]

El-Taher, A., Alshahri, F. \& Elsamana, R. (2018). Environmental impacts of heavy metals, rare earth elements and natural radionuclides in marine sediment from Ras Tanura, Saudi Arabia along the Arabian Gulf. Applied Radiation and Isotopes, 132, 95-104. [CrossRef]

Ergül, H. A., Belivermis, M., Kılıç, Ö., Topcuoglu, S. \& Çotuk, Y. (2013). Natural and artificial radionuclide activity concentrations in surface sediments of Izmit Bay, Turkey. Journal of Environmental Radioactivity, 126, 125-132. [CrossRef]

Evangeliou, N., Florou, H. \& Kritidis, P. (2013). A Survey of ${ }^{137}$ Cs in Sediments of the Eastern Mediterranean Marine Environment from the Pre-Chernobyl Age to the Present. Environ Sci Technol Lett, 1, 102-107. [CrossRef]

González-Fernández, D., Garrido-Pérez, M. C., Casas-Ruiz, M., Barbero, L. \& Nebot-Sanz, E. (2012). Radiological risk assessment of naturally occurring radioactive materials in marine sediments and its application in industrialized coastal areas: Bay of Algeciras, Spain. Environ Earth Sci, 66, 1175. [CrossRef]

Ilus, E., Klemola, S., Vartti, V. P., Mattila, J., Ikäheimonen, T. K. (2008). Monitoring of radionuclides in the vicinities of Finnish nuclear power plants in 2002 - 2004. STUK-A227 edn. STUK -Radiation and Nuclear Safety Authority, Helsinki, Finland.

Kılıç, Ö. \& Çotuk, Y. (2011). Radioactivity concentrations in sediment and mussel of Bosphorus and Golden Horn. J Radioanal Nucl Chem, 289, 627-635. [CrossRef]

Kritsananuwat, R., Sahoo, S. K., Fukushi, M., Pangza, K. \& Chanyotha, S. (2015). Radiological risk assessment of 238U, 232Th and 40K in Thailand coastal sediments at selected areas proposed for nuclear power plant sites. J Radioanal Nucl Chem, 303, 325-334. [CrossRef]

KTB (Antalya Provincial Culture and Tourism Directorate). (2019, September 13). Tourism Statistics (Antalya), Retrieved from https:// antalya.ktb.gov.tr/TR-175552/turizm-istatistikleri.html.

Othman, I., Al-Masri, M. S. \& Al-Rayyes, A. H. (2000). Sedimentation rates and pollution history of the eastern Mediterranean Sea: Syrian coast. Science of The Total Environment, 248(1), 27-35. [CrossRef] 
Özhan, S. T. (2015). Levels of some heavy metals in water and sediment compared with season and some physic-chemical parameters from Antalya Bay. Indian Journal of Geo-Marine Sciences, 44(9), 1393-1400.

Özhan, K., Akçay, I. \& Tuğrul, S. (2016). Land Base Pollution of the Turkish Mediterranean Sea. In Turan C., Salihoğlu B., Özgür Özbek E. \& Öztürk B. (Eds), The Turkish Part of the Mediterranean Sea Marine Biodiversity, Fisheries, Conservation and Governance (pp. 494-508), Turkish Marine Research Foundation (TÜDAV), İstanbul. ISBN 978975-8825-35-6

Özmen, S. F. (2020). Ecological assesment of Akkuyu nuclear power plant site marine sediments in terms of radionuclide and metal accumulation. Journal of Radioanalytical and Nuclear Chemistry., [CrossRef]

Özmen, S. F., Boztosun, I., Yavuz, M. \& Tunc, M. R. (2013). Determination of gamma radioactivity levels and associated dose rates of soil samples of the Akkuyu/Mersin using high-resolution gamma-ray spectrometry. Radiat Prot Dosim. [CrossRef]

Özmen, S. F., Cesur, A., Boztosun, I. \& Yavuz, M. (2014). Distribution of natural and anthropogenic radionuclides in beach sand samples from Mediterranean Coast of Turkey. Radiat Phys Chem, 103, 37-44. [CrossRef]

Özmen, S. F. \& Yilmaz, M. (2020). Radioactivity concentrations of farmed and wild European seabass (Dicentrarchus labrax L., 1758) in the eastern Mediterranean and risk assessment of their consumption. Regional Studies in Marine Science, 36, 101316. [CrossRef]

Pappa, F. K. Tsabaris, C., loannidou, A., Patiris, D. L., Kaberi, H., Pashalidis, I., Eleftheriou, G., Androulakaki, E. G. \& Vlastou, R. (2016). Radioactivity and metal concentrations in marine sediments associated with mining activities in lerissos Gulf, North Aegean Sea, Greece. Applied Radiation and Isotopes, 116, 22-33. [CrossRef]

Papaefthymiou, H., Gkaragkouni, A., Papatheodorou, G. \& Geraga, M. (2017). Radionuclide activities and elemental concentrations in sediments from a polluted marine environment (Saronikos GulfGreece). J Radioanal Nucl Chem, 314, 1841-1852. [CrossRef]

Petrinec, B., Franic, Z., Ilijanic, N., Miko, S., Strok, M. \& Smodis, B. (2012). Estimation of sedimentation rate in the Middle and South Adriatic Sea using ${ }^{137}$ Cs. Radiation Protection Dosimetry, 151(1), 102-111. [CrossRef]

TAEK, (2004). Türkiye'de Çernobil Sonrasi Radyasyon ve Radyoaktivite Ölçümleri. Çernobil Serisi Vol 6, 102 p. ISBN 975-8898-19-1

Tripathi, R. M., Patra, A. C., Mohapatra, S., Sahoo, S. K., Kumar, A. V. \& Puranik, V. D. (2013). Natural radioactivity in surface marine sediments near the shore of Vizag, South East India and associated radiological risk. J Radioanal Nucl Chem, 295, 1829-1835. [CrossRef]

Türkmen, M., Türkmen, A. \& Tepe, Y. (2014). Comparison of Metal Levels in Different Tissues of Seven Ray Species from Antalya Bay,
Mediterranean Sea Bull Environ Contam Toxicol, 93, 159-164. [CrossRef]

Uddin, S. \& Behbehani, M. (2018). Concentrations of selected radionuclides and their spatial distribution in marine sediments from the north-western Gulf, Kuwait. Marine Pollution Bulletin. 127, 73-81. [CrossRef]

UNSCEAR (2000). United Nations Scientific Committee on the Effects of lonizing Radiation (2000). Sources and effects of ionizing radiation. UN, New York.

Valkovic, V. (2000). Radioactivity in the Environment: Physicochemical aspects and applications. Elsevier Science, Netherlands, 696 p. ISBN10: 0444829547.

Yamagata, N., Matsuda, S., \& Kodaira, K. (1963). Run-off of cesium-137 and strontium-90 from rivers. Nature, 200, 668-669. [CrossRef]

Yaprak, G. \& Aslani, M. A. A. (2010). External dose-rates for natural gamma emitters in soils from an agricultural land in West Anatolia. $J$ Radioanal Nucl Chem, 283, 279-287. [CrossRef]

Yemenicioğlu, S. (2016). State of Pollution in North Eastern Mediterranean Basin. In: The Turkish Part of the Mediterranean Sea Marine Biodiversity, Fisheries, Conservation and Governance. In Turan C., Salihoğlu B., Özgür Özbek E. \& Öztürk B. (Eds), The Turkish Part of the Mediterranean Sea Marine Biodiversity, Fisheries, Conservation and Governance (pp. 480-493), Turkish Marine Research Foundation (TÜDAV), İstanbul. ISBN 978-975-8825-35-6.

Yilmaz, M. (2020) Effect of Cage Culture Environment on Farmed Fish in Terms of Metal Accumulation. Aquaculture Research. [CrossRef]

Yılmaz, M. \& Özmen, S. F. (2019). Kültür Minekop Balığının (Umbrina cirrosa Linnaeus, 1758) Radyolojik Risk Değerlendirmesi. Süleyman Demirel Üniversitesi Fen Edebiyat Fakültesi Fen Dergisi, 14(2): 269275. [CrossRef]

Zare, M. R., Mostajaboddavati, M., Kamali, M., Abdi, M. R. \& Mortazavi, M. S. (2012). ${ }^{235} \mathrm{U},{ }^{238} \mathrm{U},{ }^{232} \mathrm{Th},{ }^{40} \mathrm{~K}$ and ${ }^{137} \mathrm{Cs}$ activity concentrations in marine sediments along the northern coast of Oman Sea using highresolution gamma-ray spectrometry. Marine Pollution Bulletin, 64, 1956-1961. [CrossRef]

Zielinski, K. (2017). Sources, Transport and Sinks of Radionuclides in Marine Environments. In: Eds. Zielinski T., Sagan, I., Surosz, W., (Eds.), Interdisciplinary Approaches for Sustainable Development Goals, GeoPlanet: Earth and Planetary Sciences book series., (189-202pp.), Springer, Switzerland. ISBN 978-3-319-71787-6 [CrossRef]

Zuo, Z., Eisma, D., Gieles, R. \& Beks, J. (1997). Accumulation rates and sediment deposition in the northwestern Mediterranean. Deep Sea Research Part II: Topical Studies in Oceanography, 44(3-4), 597-609. [CrossRef] 